\title{
Current Status and Prospects of Pacific White Shrimp Litopenaeus vannamei (Boone, 1931) Farming in Coastal Districts of Andhra Pradesh in India
}

\author{
D. Srinivas ${ }^{1}$, Ch. Venkatrayalu ${ }^{2}$ \\ Department of Marine Biology, Vikrama Simhapuri University, Nellore-524 003, Andhra Pradesh, India
}

\begin{abstract}
The Government of India permitted the Specific Pathogenic Free (SPF) brood stock of Litopenaeus vannamei in 2009. While the majority of the output comes from Andhra Pradesh and this slowly helped the gradual transformation of shrimp culture from Penaeus monodon to L. vannamei. The culture area increased from $264 \mathrm{Ha}$ to 37,560 Ha during the period from 2009-10 to 2014-15. For the same period the shrimp production increased from 1655 tones to 2,76,077 tones in Andhra Pradesh. The shrimp exports from Andhra Pradesh increased to all time high and valued at more than Rs. 14,000 Crores for the year 2014-15. However, of late, the L.vannamei culture is also facing problems of disease menace, lack of availability of quality seed and problem of inbreed brood stock, production of seed from unregistered hatcheries, increased cost of production on account of high feed cost, spurious drugs, chemicals and probiotics, tradability problems. The situation warrants for proactive legislation of the state, establishment of aquatic quarantine facilities, brood stock multiplication centres, control of spurious seed from hatcheries and development of holistic plan for sustainable L.vannamei farming in the state.
\end{abstract}

Keywords: Litopennaeus vannamei, Status, Sustainability, Andhra Pradesh, Exports

\section{Introduction}

Brackish water aqua culture in Andhra Pradesh is almost synonymous with shrimp culture. The Black tiger shrimp culture i.e., Pennaeus monodon was introduced in late 1990s and reached to peak in 1994 and thereafter it reached its nadir. Onset of White spot disease and other diseases are suggested to be some of the important factors leading to the decline of production. Due to intensive shrimp aquaculture in most parts of the world, this activity has resulted in several problems including higher incidence of disease outbreaks (Martínez-Porchas et.al.,2010), environmental pollution of the waterways (Sansanayuth et.al.,1996). Particularly in Asia leading to massive economic losses (Lightner, 1996; Flegel, 2006). In 1999, with the introduction of fresh water prawn Macrobrachum rosenbergii (Scampi) culture, which flourished upto 2005. Later the problems in scampi like prolonged culture period, lack of availability of quality seed and growth problems in the culture led to its decline in culture. Due to continuous outbreak of WSSV in $P$. monodon culture leads to shattering of shrimp culture in India (Balakrishnan et al.,2011). By 2005, the farmers are in search of alternative species for tiger and scampi and the L. vannamei was found to be a right candidate species. The establishment of Coastal Aquaculture Authority, 2005 in India helped to regulate and frame the guidelines for the shrimp farming in coastal areas based on the previous experiences faced by farmers in tiger shrimp and they successfully introduced the Litopennaeus vannamei in 2009 by permitting to import the SPF brood stock by the hatcheries. Initially two companies, the Sarat Seafood Industries limited and BMR hatcheries were given permission in India to import brood stock from approved countries and conduct culture trials in a restricted environment. The Central Institute of Brackish water Aquaculture (CIBA), Chennai and National Bureau of Fish Genetic Resources (NBFGR), Lucknow conducted the risk analysis studies for introduction of L.vannamei in India. Following the risk analysis studies the government of India decided for a large scale introduction of commercial production L. vannamei in 2009.

\section{Area and Production}

Penneaues monodon output from Andhra Pradesh has been on declinging phase for the last 7-8 years because of introduction of Litopennaeus vannamei. The L. vannamei farming has been a major farming practice in both fresh water and also in brackish water area. The Brackish water shrimp farming is majorly practiced in six districts of coastal area of Andhra Pradesh. The total number of farmers in brackish water farming is 34,542 and total area under brackish water shrimp culture is 35,925.9 $\mathrm{Ha}$ as on 2015 The Nellore district is a major district where brackish water shrimp area is practiced with an extent of 5691.86 Ha and Vizianagaram district is lowest with only $52.49 \mathrm{Ha}$. The number of farmers practicing brackish water aquaculture is more in Krishna district with 18805 farmers while it is least in Vizianagaram district with 57 farmers. The area wise and number of farmers district wise is shown in table -1 . 


\section{International Journal of Science and Research (IJSR) \\ ISSN (Online): 2319-7064}

Index Copernicus Value (2013): 6.14 | Impact Factor (2014): 5.611

Table 1: District wise brackish water shrimp farming in Andhra Pradesh state

\begin{tabular}{|c|c|c|c|c|c|c|}
\hline \multirow{2}{*}{ Name of the District } & \multicolumn{2}{|c|}{ Below 2.00 Ha. } & \multicolumn{2}{c|}{ Above 2.00 Ha. } & \multicolumn{3}{c|}{ Total } \\
\cline { 2 - 7 } & Number of farmers & Extent in Ha & Number of farmers & Extent in Ha & Number of farmers & Extent in Ha \\
\hline Srikakulam & 549 & 438.46 & 33 & 270 & 582 & 708.32 \\
\hline Vizianagaram & 56 & 45.21 & 1 & 7 & 57 & 52.49 \\
\hline Visakhapatnam & 27 & 36.86 & 34 & 321 & 61 & 357.89 \\
\hline East Godavari & 5543 & 5019.22 & 51 & 141 & 5594 & 5160.63 \\
\hline West Godavari & 1786 & 1743.37 & 136 & 570 & 1922 & 2312.87 \\
\hline Krishna & 18753 & 14842.1 & 52 & 144 & 18805 & 14986.3 \\
\hline Guntur & 3050 & 3025.77 & 116 & 487 & 3166 & 3512.72 \\
\hline Prakasam & 1834 & 2439.32 & 89 & 704 & 1923 & 3142.83 \\
\hline Nellore & 2183 & 3230.93 & 249 & 2461 & 2432 & 5691.86 \\
\hline Total & 33781 & 30821.2 & 761 & 5105 & 34542 & 35925.9 \\
\hline
\end{tabular}

(Source: Department of Fisheries, Govt. of Andhra Pradesh, 2015)

Further, the unique feature of Andhra Pradesh shrimp farming is that, the shrimp is also farmed in low saline waters mostly in East Godavari, West Godavari, Krishna and Nellore districts. The district wise and area wise aquaculture farming in fresh water is shown in table-2

Table 2: District wise registered fresh water aquaculture farming in Andhra Pradesh state

\begin{tabular}{|c|c|c|c|c|c|}
\hline \multirow[b]{2}{*}{$\begin{array}{l}\text { Sl. } \\
\text { No }\end{array}$} & \multirow[b]{2}{*}{ District } & \multicolumn{2}{|c|}{ Total Registered } & \multicolumn{2}{|c|}{ Extent in $\mathrm{Ha}$} \\
\hline & & $\begin{array}{l}\text { Number } \\
\text { of farms }\end{array}$ & $\begin{array}{c}\text { Extent in } \\
\text { Ha }\end{array}$ & Fish & $\begin{array}{l}\text { Prawn/ } \\
\text { Shrimp }\end{array}$ \\
\hline 1 & Srikakulam & 37 & 188.55 & 188.55 & 0 \\
\hline 2 & Vizianagaram & 39 & 86.28 & 86.28 & 0 \\
\hline 3 & Visakhapatnam & 22 & 9 & 9 & 0 \\
\hline 4 & East Godavari & 3671 & 4442 & 2666 & 1776 \\
\hline 5 & West Godavari & 16850 & 59201 & 39665 & 19536 \\
\hline 6 & Krishna & 10415 & 28426 & 24000 & 4426 \\
\hline 7 & Guntur & 129 & 546.812 & 546.812 & 0 \\
\hline 8 & Prakasam & 140 & 478.27 & 478.27 & 0 \\
\hline \multirow[t]{2}{*}{9} & Nellore & 1774 & 2599 & 0 & 2599 \\
\hline & Total & 33077 & 95976.9 & 67639.9 & 28337 \\
\hline \multicolumn{6}{|c|}{$100 \%$} \\
\hline \multicolumn{5}{|c|}{$90 \%$} & $80 \%$ \\
\hline \multicolumn{6}{|c|}{$70 \%$} \\
\hline \multicolumn{6}{|c|}{$60 \%$} \\
\hline \multicolumn{6}{|c|}{$50 \%$} \\
\hline \multicolumn{6}{|c|}{$30 \%$} \\
\hline \multicolumn{6}{|c|}{$20 \%$} \\
\hline \multicolumn{6}{|c|}{$10 \times$} \\
\hline & $2000 \cdot 10$ & 2010-11 & 2011-12 & $2012 \cdot 13 \quad 20$ & $3-14 \quad 2014-15$ \\
\hline
\end{tabular}

(Source: Department of Fisheries, Govt. of Andhra Pradesh, 2015)

The table-2 shows that, the fresh water shrimp farming area is more in West Godavari district which is about 19,536 Нa of total area of $28,337 \mathrm{Ha}$ which is $68.9 \%$. It is lowest in Nellore with 2599 Ha.

\section{Comparison of production of $L$. vannamei in Andhra Pradesh and rest of the India:}

The share of Andhra Pradesh in Litopennaeus vannamei culture has been increasing in terms of both production and area Andhra Pradesh contributes a major share in production and area in culture of Litopennaeus vannamei. The production and area of Andhra Pradesh and rest of India is shown under Figure -1

Figure 1: Percentage of Litopenaues vannamei farming area and total production in Andhra Pradesh versus rest of India (2009-10 to 2014-15) (Source : MPEDA, India )

\section{Exports}

The Shrimp exports has under a major surge after introdcution of Litopennaeus vannamei in India. Incidentally, the share of Andhra Pradesh in country's shrimp and marine exports has been also increasing. The year wise Shrimp exports is shown in table-3
Table 3: Shrimp and marine exports in terms of value in Andhra Pradesh versus India (2009-10 to 2014-15)

\begin{tabular}{|c|c|c|c|c|}
\hline $\begin{array}{c}\text { S. } \\
\text { No }\end{array}$ & Year & $\begin{array}{c}\text { Exports } \\
\text { from India } \\
\text { (in Rs. } \\
\text { Crores) }\end{array}$ & $\begin{array}{c}\text { Exports from } \\
\text { Andhra Pradesh } \\
\text { (in Rs. Crores) }\end{array}$ & $\begin{array}{c}\text { Percentage of } \\
\text { Andhra Pradesh } \\
\text { contribution }\end{array}$ \\
\hline 1 & $2009-10$ & 10048 & 2100 & $20 \%$ \\
\hline 2 & $2010-11$ & 12901 & 2400 & $18.6 \%$ \\
\hline 3 & $2011-12$ & 16597 & 2727 & $16 \%$ \\
\hline 4 & $2012-13$ & 18856 & 3125 & $16.57 \%$ \\
\hline 5 & $2013-14$ & 30200 & 12100 & $40 \%$ \\
\hline 6 & $2014-15$ & 33600 & 14200 & $42 \%$ \\
\hline
\end{tabular}

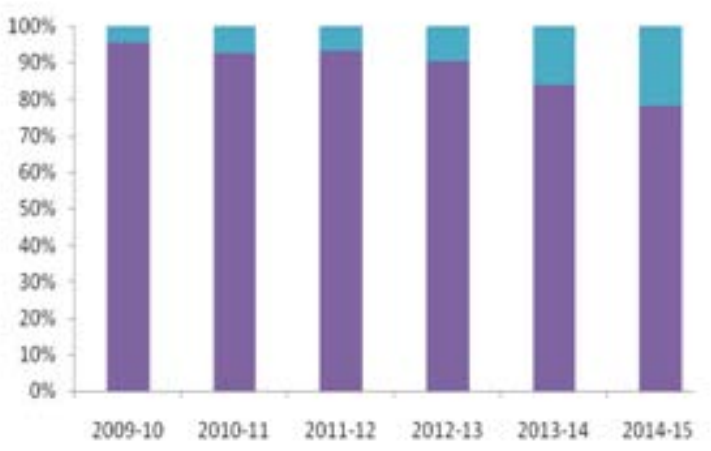

IE Production in (W) Andhra pradesh \# 


\section{International Journal of Science and Research (IJSR) \\ ISSN (Online): 2319-7064 \\ Index Copernicus Value (2013): 6.14 | Impact Factor (2014): 5.611}

(Source : MPEDA, India )

Low Saline Farming: Litopennaeus vannamei culture is practiced in low saline waters in the district of West Godavari primarily as the brackish water area is less comparatively. Though the farming of shrimp in low saline waters is not a new practice but farming the exotic species in low saline waters is a novel concept. It is observed that, the incidence of disease occurrence is comparatively less when compared to brackish waters. Several authors have reported on the growth and survival of $L$. vannamei in different salinities and densities (Wyban et.al, 1988; Samocha et. al, 1993; Samocha et. al, 1999; Emberson and Samocha, 1999). Karthikean 1994 and Gunalan, 2010 recommended a salinity range of 10 - 35 ppt was ideal for shrimp culture. Samocha et. al, 2004; Sowers and Tomasso, 2006 reported that growth is higher in low saline (2 ppt) water than in sea water.

\section{Constraints and Challenges}

The main constraints expressed by farmers is the viral and bacterial disease outbreaks. The quality of shrimp seed from hatcheries is also the great concern for the majority of farmers. The erratic power supply, differential rates of power tariff for shrimp and agriculture, high feed cost, poor cooperation among farmers, poor water quality, price of seed are other constraints.

The greatest challenge is the sustainability of Litopennaeus vannamei culture as the shrimp is already affected with diseases. The strict practice of bio-security measures needs to be implemented by every farmer as the stocked species is an exotic and Specific Pathogen Free (SPF) species but not free from all the diseases. It is observed that, the farms which practice bio -security measures strictly are least effected with the disease. The business of unregulated use and sale of chemicals, drugs and probiotics is yet another challenge. Mushrooming of hatcheries in the name of brood stock multiplication centers needs to be regulated by the government.

\section{Conclusions}

Shrimp farming is highly resilient in Andhra Pradesh.. The farming system in every district is unique in certain aspects. While some districts practice the shrimp culture in low saline waters whereas, other districts practice in medium and high salinity waters. The incidence of disease is also differing in different districts, White Spot Syndrome Virus (WSSV) and Running Mortality Syndrome (RMS) is common in all shrimp farming districts. The white gut, white muscle and muscle cramp is more in Nellore, Prakasam and West Godavari districts. The menace of spurious drugs is wide spread in all districts. The lack of availability of quality seed is the major problem for sustainability of the shrimp farming.

In this connection it was suggested that a mechanism for seed certification by the state fisheries department has to be developed to ensure supply of healthy and quality shrimp seed from import of SPF brood stock to export the species. There is need to bring a comprehensive legislation on the practice of BMPs in general and quality of seed, particularly in the shrimp farming. The problems of small and marginal framers in shrimp culture can be better addressed by organising them into Farmer Producer Organisations (FPOs). There is a need to bring Insurance and the government should contribute certain percentage of the premium to reduce economic losses and risks involved in the shrimp farming. It is high time that, the state government should involve the private sector along with farmers participation for sustainable Litopennaeus vannamei farming in Andhra Pradesh.

\section{Acknowledgements}

The authors are thankful to the Marine Products Export Development Authority (MPEDA, Kochi), The Chief Executive of National Fisheries Development Board, Hyderabad and Dr.R.Jaya Kumar, Senior Scientist, CMFRI Mandapam. We are also grateful to Sri. Rama Sankar Naik, IAS, Commissioner of Fisheries, Andhra Pradesh, India.

\section{References}

[1] Sansanayuth P, Phadungchep A, Ngammontha S, Ngdngam S, Sukasem P, Hoshino H. Shrimp pond effluent: pollution problems and treatment by constructed wetlands. Water Sci Tech 1996; 34:93-98.

[2] Martínez-Porchas M, Martínez-Córdova LR, PorchasCornejo MA, López-Elías JA. Shrimp polyculture: a potentially profitable sustainable but uncommon aquacultural practice. Rev Aquacult 2010; 2:73-85.

[3] Flegel, T.W. 2006. Detection of major penaeid shrimp viruses in Asia, a historical perspective with emphasis on Thailand. Aquaculture 258: 1-33.

[4] Gunalan Balakrishnan. Soundarapandian Peyail. Kumaran Ramachandran, AnandTheivasigamani, Kotiya Anil Savji, Maheswaran Chokkaiah and Pushparaj Nataraj. 2011. Growth of Cultured White Leg Shrimp Litopenaeus Vannamei (Boone 1931) In Different Stocking Density., Advances in Applied Science Research, 2 (3): 107-113.

[5] Lightner, D.V. (1996). A Handbook of Shrimp Pathology and Diagnostic Procedures for Diseases of Cultured Penaeid Shrimp. World Aquaculture Society, Baton Rouge, LA, USA. 304 p.

[6] Wyban JA, Sweeney JN, Kanna RA, J. World Aquacult. Soc., 1988,19:210-217.

[7] Samocha T, Lawrence AL, Biedenbach JM, J. Applied Aquacult., 1993, 2(1):55-64.

[8] Samocha TM, Lawrence AL, Bray WA, Collins CA, Castille FL, Lee PG, Davies CJ, Production of marketable Litopenaeus vannamei in green house enclosed raceways in the Arizona desert using ground saline water. 1999, p. 669. In: Book of Abstracts. World Aquacult. Soc. Ann. Conf., Sydney, Australia.

[9] Emberson CR, Samocha TM, and Wood GF, Use of ground saline water for commercial production of Litopenaeus vannamei in the Sonora desert, Arizona, USA. 1999, p. 668. In: Book of Abstracts. World Aquacult. Soc. Ann. Conf., Sydney, Australia.

[10] Karthikean J, Aquaculture (Shrimp farming) its influence on environment. Technical Paper submitted to the Seminar Our Environment-Its challenges to 


\section{International Journal of Science and Research (IJSR) \\ ISSN (Online): 2319-7064}

Index Copernicus Value (2013): 6.14 | Impact Factor (2014): 5.611

development projects. American Society of Civil Engineers, Culcutta, India 1994.

[11] Gunalan B, Soundarapandian P, and Dinakaran GK, Asian Journal of Agricultural Sciences 2010,2(1): 5-8.

[12] Samocha T, Addison M, Lawrence L, Craig A, Collins FL, Castille WA, Bray CJ, Davies PG, Lee G, Wood F, J. Appl. Aquac. 2004,15, 1-19.

[13] Sowers AD, Tomasso JR, J. World Aquac. Soc. 2006, 37, 214-217. 